\title{
COMPARATIVE BIOACTIVITY OF PLANT EXTRACTS AND SYNTHETIC INSECT GROWTH REGULATORS AGAINST Spodoptera litura (F.) (LEPIDOPTERA: NOCTUIDAE)
}

\author{
Rosma Hasibuan ${ }^{1}$, Purnomo $^{1}$, Lestari Wibowo ${ }^{1}$, Izzaturrijal ${ }^{2}$, \& Jamalam Lumbanraja ${ }^{3}$ \\ ${ }^{1}$ Department of Plant Protection, Faculty of Agriculture, University of Lampung, Indonesia \\ ${ }^{2}$ Department of Agrotechnology, Faculty of Agriculture, University of Lampung, Indonesia \\ ${ }^{3}$ Department of Soil Science, Faculty of Agriculture, University of Lampung, Indonesia \\ Jl. Prof. Sumantri Brodjonegoro No 1 Bandar Lampung, 35145 \\ E-mail: rosma.hasibuan@fp.unila.ac.id
}

\begin{abstract}
Comparative bioactivity of plant extracts and synthetic insect growth regulators against Spodoptera litura (F.) (Lepidoptera: Noctuidae). Laboratory bioassays were conducted to compare the effects of the leaf extract of Acalypha indica L. (Euphorbiaceae) with synthetic insect growth regulators (IGRs) triflumuron and buprofezin against Spodoptera litura (F.). The experiment was set up as a randomized complete block design (RCBD). The treatments were two concentrations of $A$. indica extracts 1000 and $2000 \mathrm{ppm}$, two concentrations of buprofezin 100 and $200 \mathrm{ppm}$, two concentrations of triflumuron 120 and $240 \mathrm{ppm}$ and control. Each treatment was replicated three times. Second instar larva of S. litura were used for the bioassays. Mortality and biological variables of treated and control larvae were recorded daily. The results indicated that the application of $A$. indica extracts and synthetic IGRs (buprofezin \& triflumuron) significantly caused the $S$. litura mortality throughout the experimental period. At first, the toxicity of triflumuron on larval $S$. litura was significantly higher compared to those of buprofezin and Acalypha indica leaf extract. However, at the end of experimental period all treatments caused high mortality on S. litura, and those all were significantly different from control. The treatments also caused abnorrmal growth in larval, pupal, and adult stages. While in the control, larvae molted into normal adults. The results indicated that the use of biorational control agents such as synthetic insect growth regulators (IGRs) and those based on naturally derived products such as botanical insecticides show promise as a potential tool in S. litura management programs.
\end{abstract}

Key words: abnormal growth, Acalypha indica, buprofezin, mortality, Spodoptera litura, triflumuron

\section{INTRODUCTION}

Spodoptera litura (F.) (Lepidoptera: Noctuidae) is one of the most economically important insect pests in many countries, including in Indonesia, Korea, India, Japan, China, and other countries of Southeast Asia (Yang et al., 2019; Garad et al., 1985; Bae \& Park, 1999; Aitkenhead et al., 1974). Rao et al. (1993) reported $S$. litura as a polyphagous pest that has about 150 host species. Larvae feed gregariously and may completely devour the leaves and causing considerable economic loss to many vegetables and field crops, such as corn, peanut, soybean, tomato, cabbage, potato, and tobacco (Brown \& Dewhurst, 1975; Kalshoven, 1981; Ghumare \& Mukherjee, 2003; Ahmad et al., 2013). This insect pest has high reproductive potential and can lay hundreds of eggs in egg batches (Shahout et al., 2011; Chen \& Hsiao, 1984). The economic importance of $S$. litura is owing to its high increase rate and wide host spectrum. In Indonesia, the yield loss in soybean due to S. litura attack varies between 23 and 45\% (Fattah \& Ilyas, 2016). Moreover, Marwato \& Suharso (2008) reported that the yield loss in soybean can be as high as $80-100 \%$.

Currently, control of $S$. litura relies mainly on the application of chemical insecticides, including carbamates, pyrethroids and organophosphates (Liburd et al., 2000). It has been known that widespread and continuous use of these chemical insecticides cause environmental problems, negative impact on beneficial insects, and leads to the development of insect resistance (Ahmad et al., 2007; Perry et al., 1998; Ecobichon, 1996). Management of $S$. litura using conventional insecticides has failed mainly because of insecticide resistance (Onstad et al., 2018; Jepson et al., 2014; Farrar et al., 2018). Finding environmentally safe of pest management strategies is a necessity. 
The alternative control tactics that show promise for $S$. litura resistant management programs is the use of biorational control agents such as synthetic insect growth regulators (IGRs) and botanical insecticides. IGRs differ widely from the commonly used insecticides, as they exert their insecticidal effects through their influence on development, metamorphosis and reproduction of the target insects by disrupting the normal activity of the endocrine system (Khan, 2016; Dhadialla et al., 1998; Retnakaran et al., 1985; Khatun et al., 2017; Khatter, 2015). These compounds have been tested successfully against several insect species namely, the papaya mealybug Paracoccus marginatus (Khan, 2016); the cotton leaf worm Spodoptera littoralis (Khatter, 2015; Nasr et al., 2010); the brown planthopper Nilaparvata lugens (Kanaoka et al., 1996; Uchida et al., 1985; Izawa et al., 1985); the rice weevil Sitophilus oryzae (Das, 2013; Merzendorfer \& Zimoch, 2003); the earthworm Aporrectodea caliginosa (Badawy et al., 2013); brinjal shoot and fruit borer Leucinodes orbonalis (Das \& Islam, 2014); the sweet potato whitefly Bemisia tabaci (Ishaaya et al., 1998); and the Colorado potato beetle Leptinotarsa decemlineata (Karimzadeh et al., 2007).

An example of insect growth regulators that has been studied is chitin synthesis inhibitors (CSIs). This insecticide inhibit chitin synthesis in insects that results in a disruption of the molting process (Retnakaran et al., 1985; Karimzadeh et al., 2007). Moreover, Merzendorfer \& Zimoch (2003) found that CSIs prevent the formation of chitin, a carbohydrate that is an important structural component of the insect's exoskeleton that is required before a larval molt. Ttriflumuron and buprofezin are the example of CSIs. In other case, it has been reported that various natural insecticides (derived from plants) can also work as IGRs. One of the plants species that can act as IGRs is the indian nettle, Acalypha indica L. (Euphorbiaceae) (Kamalakannan et al., 2015). Some studies on A. indica proved that the content of plant extracts can inhibit the growth and development of insect pest, Aedes albopictus mosquito (Ashwini et al., 2017); Anopheles stephensi (Govindarajan et al., 2008); Aedes aegypti (Kamalakannan et al., 2015; Pratiwi et al., 2015); Dysdercus cingulatus (Sahayaraj \& Shoba, 2012); Leucinodes orbonali (Manibala \& Praveena, 2017). Based on information above, the objective of this study was to compare the effect of two synthetic IGRs triflumuron and buprofezin with plant-derived insect growth regulators (A. indica extract) against, $S$. litura under laboratory conditions.

\section{MATERIALS AND METHODS}

Research Site. All experiments were conducted in the Laboratory of Arthropod Pests, Faculty of Agriculture, University of Lampung from February to Juni 2018.

Insect Rearing. S. litura were initiated from freshly collected larvae from the corn field at the Agricultural Experimental Field of University of Lampung. The insect colonies were confined in transparant plastic cage (14 $\mathrm{cm}$ in diameter; $30 \mathrm{~cm}$ in height) with its top and sides cut off and covered with fine mesh nylon net for air ventilation. Larvae were provided daily with fresh castor bean leaves (Jatropha curcas). The emerged adults were provided with $10 \%$ honey solution on a cotton wick as a food source. Moths were allowed to lay eggs on the cage, then the egg culsters were collected daily, and transferred into Petri dishes until hatching. All rearing cages were maintained under laboratory conditions of $27 \pm 2{ }^{\circ} \mathrm{C}$ and $\mathrm{RH} 70 \pm 5 \%$.

Preparation of Plant Extract. The $A$. indica leaves were collected from the area around Bandar Lampung, washed with tap water and rinsed with distilled water to remove the sand particles. The leaves were air dried for a week at room temperature $\left(27^{\circ} \mathrm{C}\right)$. The dried leaves were grounded into fine powder using a blender machine. An amount of $100 \mathrm{~g}$ powder of the leaf material was mixed with $1000 \mathrm{~mL}$ ethanol on 2L Erlenmeyer flasks to make suspension. Plant suspension was continuously shaken with magnetic stirrer at $180 \mathrm{rpm} /$ min for $24 \mathrm{~h}$ at room temperature. The suspensions were filtered through Whatman No. 1 paper via a Buchner funnel. The residue was reextracted again twice under the same procedure as before. All the crude plant extracts were evaporated to dryness using a Rotary Evaporator at $50 \mathrm{~mm} \mathrm{Hg}$ pressure and $50^{\circ} \mathrm{C}$ to get thick and viscous materials and stored in air tight bottles. Suspensions of two concentrations of plant extracts, 1000 and $2000 \mathrm{ppm}$ were prepared by dissolving $0.1 \mathrm{~g}$ and 0.2 of the evaporated leave extracts in $1000 \mathrm{~mL}$ distilled water. To this mixture, $0.1 \mathrm{~mL}$ of Tween $80(0.05 \%)$ was added as an emulsifier.

Preparation of Chemicals (IGRs). The IGRs tested were Lugen $100 \mathrm{EC}$ (10\% buprofezin) from PT Nufarm, Indonesia and Destello $480 \mathrm{SC}$ (12\% triflumuron) from PT Bayer, Indonesia. Two concentrations, 100 and 200 ppm of buprofezin (as the recommendation of doses range of each product) were prepared by dissolving 1 $\mathrm{mL}$ and $2 \mathrm{~mL}$ of Lugen $100 \mathrm{EC}$ in $1000 \mathrm{~mL}$ distilled 
water. While, two concentrations 120 and $240 \mathrm{ppm}$ of triflumuron were provided by dissolving $1 \mathrm{~mL}$ and $2 \mathrm{~mL}$ of Destello $480 \mathrm{SC}$ in $1000 \mathrm{~mL}$ distilled water.

Toxicity and Growth-Inhibitory Bioassay. A total of 7 treatments was made by preparing: two concentrations of A. indica extracts 1000 and 2000 ppm, two concentrations of buprofezin 100 and $200 \mathrm{ppm}$, two concentrations of triflumuron 120 and $240 \mathrm{ppm}$, and control (C). Control larvae were treated with distilled water only. Three replicates (each of 10 larvae per concentration) were used. All treatments were arranged in randomized complete block design (RCBD). Second instar larvae of $S$. litura were placed in sterile plastic Petri dishes, 10 individuals in each dish. All individual insects were treated with each suspension and distilled water by using modified sprayer. The treated larvae were feed with fresh castor bean leaves and maintained until pupation. Mortality and biological variables of treated and control larvae were recorded daily. These biological aspects include; number of abnormal larvae, number of normal and abnormal pupa, and number of normal and abnormal adults.

Data Analysis. Data were subjected to analysis of variance (ANOVA) and means were separated by Tukey's HSD (honestly significant differerence) at $\alpha=0.05$. Values were represented as mean \pm SE. Features of impaired development were recorded in pictures.

\section{RESULTS AND DISCUSSION}

The results of one way ANOVA showed that the application of synthetic IGRs (buprofezin and triflumuron) and extract of $A$. indica significantly affected the mortality of $S$. litura at 1, 4, 6, and 8 days after treatment (Table 1). Moreover, it was reveal that the mortality of $S$. litura was gradually increased in each of consecutive observations. The larvae were considered dead if they did not move when slightly touched with a fine camel brush.

After $1 \mathrm{~d}$ exposure, mortality began to occur for triflumuron $120 \mathrm{ppm}(43.3 \pm 3.3 \%)$ and $240 \mathrm{ppm}$ $(73.3 \pm 3.3 \%)$ treatments. However, no mortality was observed at the treatment of buprofezin $100 \mathrm{ppm}$ and $200 \mathrm{ppm}$ and $A$. indica extract at $1000 \mathrm{ppm}$. According to Das (2013), buprofezin had no direct effect on the mortality of rice weevils Sitophilus oryzae L. (Coleoptera: Curculionidae) regardless the concentrations. In addition, Khatun et al. (2017) and Merzendorfer \& Zimoch (2003) stated that buprofezin was not directly toxic to insects but potentially reduce pest populations by disrupting normal growth and development through disruption of chitin synthesis. Moreover, multiple comparison means by Tukey test revealed that the mortality of S. litura treated with triflumuron $240 \mathrm{ppm}(73.3 \pm 3.3 \%)$ was significantly higher than that of with $A$. indica extract $2000 \mathrm{ppm}$ $(16.7 \pm 3.3 \%)$.

At $4^{\text {th }}$ day after, treatment maximum mortality $(100 \%)$ was found to occur in the larvae treated with triflumuron $240 \mathrm{ppm}$ followed by those treated with triflumuron $120 \mathrm{ppm}(73.3 \pm 3.3 \%)$, and $A$. indica extract at $2000 \mathrm{ppm}(50.0 \pm 5.8 \%)$. These results agree with findings of Khatter (2015) who noted that triflumuron exhibited the highest toxic action against the second instar of $S$. littoralis larvae. Moreover, at $8^{\text {th }}$ day of observation, we found that all treatments caused an equally high mortality of on S. litura and those were significantly different with the control.

In addition to mortality, we also evaluated the effects of synthetic IGRs (buprofezin, triflumuron) and $A$. indica extracts on growth and development of S. litura. Several morphological abnormalities were observed including deformation of larva, pupa, and adult of $S$. litura. The results clearly indicate that the larval deaths of $S$. litura (Table 1 ) were closely related with the molting abnormalities of larva (Table 2). Moreover, our data showed that application of $A$. indica extract and synthetic IGR insecticides (buprofezin and triflumuron), significantly cause abnormal growth of $S$. litura larvae (Table 2). Most of the larvae treated with these compounds showed symptoms of molting failure before larval death. Several morphological abnormalities were observed in larval development (Figure 1). Our result indicated that treated larvae with triflumuron became pale and discolored in the posterior end of the abdomen indicated that this insecticide inhibits chitin biosynthesis and cuticle formation (Figure 1A). The new cuticle was weakened, leads to an unsuccessful molt and eventual death. Similar results were observed by Khatter (2015) who found that the second larval instar of S. littoralis (Lepidoptera: Noctuidae) treated with triflumuron showed incomplete chitin synthesis. The similar symptom was also observed on Manduca sexta treated with chitin synthesis inhibitors (Abdel-Monem et al., 1980). In addition, our result also indicated that the application of buprofezin on S. litura larvae caused failure in shedding off the larval exuviae (Figure 1B). In this case, the newly molted $S$. litura larvae died while shedding the old cuticle and head capsule. Similar findings were also reported by Izawa et al. (1985) who found that the death of Nilaparvata lugens nymphs 
treated with buprofezin was attributed to the chitin synthesis inhibitors act during metamorphosis which causes abortive molting. Badawy et al. (2013) noted that a significant growth inhibition on the earthworm, Aporrectodea caliginosa, was also seen when exposed to buprofezin and triflumuron. Buprofezin and triflumuron are chitin synthesis inhibitors, act by interfering with chitin synthesis. Therefore, most of the larvae treated with these compounds showed symptoms at molting. In other words, treated larvae fail to complete the molting process due to inhibition of the synthesis of new cuticle, specifically, chitin biosynthesis. The dead larvae showed shrunken body compared to the untreated larvae (Figure 1C). The results showed that the action

Table 1. Larval mortality (mean \pm SE) of $S$. litura treated synthetic IGRs (buprofezin \& triflumuron) and A. indica extract

\begin{tabular}{lrrrr}
\hline \multirow{2}{*}{ Treatment } & \multicolumn{4}{c}{ Mortality (\%) at different days after treatment } \\
\cline { 2 - 5 } & \multicolumn{1}{c}{1} & \multicolumn{1}{c}{4} & \multicolumn{1}{c}{6} \\
\hline Triflumuron $120 \mathrm{ppm}$ & $43.3 \pm 3.3 \mathrm{~b}$ & $73.3 \pm 3.3 \mathrm{a}$ & $83.3 \pm 0.0 \mathrm{a}$ & $93.3 \pm 3.3 \mathrm{a}$ \\
Triflumuron 240 ppm & $73.3 \pm 3.3 \mathrm{a}$ & $100.0 \pm 0.0 \mathrm{a}$ & $100.0 \pm 0.0 \mathrm{a}$ & $100.0 \pm 0.0 \mathrm{a}$ \\
Buprofezin 100 ppm & $0.0 \pm 0.0 \mathrm{~b}$ & $20.0 \pm 5.8 \mathrm{c}$ & $63.3 \pm 5.8 \mathrm{~b}$ & $80.0 \pm 5.8 \mathrm{a}$ \\
Buprofezin 200 ppm & $0.0 \pm 0.0 \mathrm{~b}$ & $3.3 \pm 2.1 \mathrm{c}$ & $76.7 \pm 8.8 \mathrm{a}$ & $93.3 \pm 3.3 \mathrm{a}$ \\
A.indica extracts 1000 ppm & $0.0 \pm 0.0 \mathrm{~b}$ & $3.3 \pm 2.1 \mathrm{c}$ & $56.7 \pm 8.8 \mathrm{~b}$ & $83.3 \pm 16.7 \mathrm{a}$ \\
A.indica extracts $2000 \mathrm{ppm}$ & $16.7 \pm 3.3 \mathrm{~b}$ & $50.0 \pm 5.8 \mathrm{~b}$ & $76.7 \pm 3.3 \mathrm{a}$ & $90.0 \pm 3.3 \mathrm{a}$ \\
Control & $0.0 \pm 0.0 \mathrm{~b}$ & $3.3 \pm 5.38 \mathrm{c}$ & $3.3 \pm 3.3 \mathrm{c}$ & $3.3 \pm 3.3 \mathrm{~b}$ \\
\hline F Value & 174.78 & 115.20 & 40.33 & 21.58 \\
Pr $>$ F & 0.000 & 0.000 & 0.000 & 0.000 \\
\hline
\end{tabular}

Means followed by the same letter within the same columns are not significantly different (Tukey's HSD test; $\alpha=$ $0.05)$.

Table 2. Effects of synthetic IGRs (buprofezin \& triflumuron) and A. indica extracts on the development* aspects of the S.litura

\begin{tabular}{lcccccc}
\hline \multirow{2}{*}{ Treatment } & \multicolumn{2}{c}{ Larval stage (\%) } & \multicolumn{2}{c}{ Pupal stage (\%) } & \multicolumn{2}{c}{ Adult stage (\%) } \\
\cline { 2 - 7 } & Death & $\begin{array}{c}\text { Malformed } \\
\text { larvae }\end{array}$ & Pupation & $\begin{array}{c}\text { Malformed } \\
\text { pupae }\end{array}$ & $\begin{array}{c}\text { Adults } \\
\text { emergence }\end{array}$ & $\begin{array}{c}\text { Malformed } \\
\text { adults }\end{array}$ \\
\hline $\begin{array}{l}\text { Triflumuron } \\
120 \text { ppm }\end{array}$ & $93.3 \pm 3.3 \mathrm{a}^{* *}$ & $93.3 \pm 3.3 \mathrm{a}^{* *}$ & $6.7 \pm 2.8 \mathrm{~b}^{* *}$ & $6.7 \pm 2.8$ & $0.0 \pm 0.0 \mathrm{~b}^{* *}$ & $0.0 \pm 0.0$ \\
$\begin{array}{l}\text { Triflumuron } \\
\text { 240 ppm }\end{array}$ & $100.0 \pm 0.0 \mathrm{a}$ & $100.0 \pm 0.0 \mathrm{a}$ & $0.0 \pm 0.0 \mathrm{~b}$ & $0.0 \pm 0.0$ & $0.0 \pm 0.0 \mathrm{~b}$ & $0.0 \pm 0.0$ \\
$\begin{array}{l}\text { Buprofezin } \\
100 \text { ppm }\end{array}$ & $80.0 \pm 5.8 \mathrm{a}$ & $80.0 \pm 5.8 \mathrm{a}$ & $20.0 \pm 0.0 \mathrm{~b}$ & $10.0 \pm 3.3$ & $10.0 \pm 3.3 \mathrm{~b}$ & $10.0 \pm 3.3$ \\
$\begin{array}{l}\text { Buprofezin } \\
200 \text { ppm }\end{array}$ & $93.3 \pm 3.3 \mathrm{a}$ & $93.3 \pm 3.3 \mathrm{a}$ & $6.7 \pm 2.8 \mathrm{~b}$ & $3.3 \pm 2.8$ & $3.3 \pm 2.8 \mathrm{~b}$ & $3.3 \pm 2.8$ \\
$\begin{array}{l}\text { A.indica } \text { extracts } \\
1000 \mathrm{ppm}\end{array}$ & $83.3 \pm 16.7 \mathrm{a}$ & $83.3 \pm 16.7 \mathrm{a}$ & $16.7 \pm 5.8 \mathrm{~b}$ & $10.0 \pm 3.3$ & $6.7 \pm 2.8 \mathrm{~b}$ & $6.7 \pm 2.8$ \\
$\begin{array}{l}\text { A.indica } \text { extracts } \\
\text { 2000 ppm }\end{array}$ & $90.0 \pm 3.3 \mathrm{a}$ & $90.0 \pm 3.3 \mathrm{a}$ & $10.0 \pm 2.3 \mathrm{~b}$ & $6.7 \pm 2.8$ & $3.3 \pm 2.8 \mathrm{~b}$ & $3.3 \pm 2.8$ \\
Control & $3.3 \pm 3.3 \mathrm{~b}$ & $3.3 \pm 3.3 \mathrm{~b}$ & $96.7 \pm 5.8 \mathrm{a}$ & $0.0 \pm 0.0$ & $96.7 \pm 5.8 \mathrm{a}$ & $0.0 \pm 0.0$ \\
\hline F Value & 21.58 & 23.16 & 19.22 & 1.64 & 13.43 & 1.13 \\
Pr $>$ F & 0.000 & 0.000 & 0.000 & 0.208 & 0.000 & 0.395 \\
\hline
\end{tabular}

* insect development was calculated from larvae till adult emergence; ** Means followed by the same letter within the same columns are not significantly different (Tukey's HSD test; $\alpha=0.05$ ). 
of this botanical insecticide caused larval-pupal intermediate appearance with anterior half (head and thorax) as pupa whereas abdomen as larva forms (Figure 1C). Similar findings were also reported by others. Manibala \& Praveena (2017) found that the A. indica extract act as an antifeedant and insect growth regulator against fruit borer, Leucinodes orbonalis (Lepidoptera: Pyralidae). This abnormal growth may be related to the fact that extract of $A$. indica may act as a growth regulator inhibitor on $S$. litura. Moreover, Sharma \& Gupta (2009) found that A. indica extract had antifeedant effect on the cabbage white butterfly, Pieris brassicae (L) (Lepidoptera: Pieridae). Nazri et al. (2016) studied the phytochemical constituents of $A$. indica and reported the presence of various secondary metabolites, namely tannins, phenolics, flavonoids, terpenoids, and saponins. Relatively similar results were found by Mohan et al. (2012), phytochemical screening of $A$. indica leaves extract revealed the presence of alkaloids, tannins, steroids, saponins, flavanoids, glycosides and phenolic compounds. Other study by Sahayaraj \& Shoba (2012) showed that $A$. indica extracts offer a wide array of bioactive compounds which are sufficiently toxic and alters the growth and development of Dysdercus cingulatus.
Our results showed that all treated $S$. litura with triflumuron died at larval stage. Therefore, the abnormalities in pupation were only observed on $S$. litura treated with buprofezin and $A$. indica leaves extract (Table 2; Figure 2A \& B). Malformed pupae were not able to complete pupation, while in the control, all $S$. litura succeeded to form a normal pupa (Figure 2C). In buprofezin case, treated $S$. litura showed larval-pupal intermediate, consisting of larval head and thorax, whereas abdomen of some pupae were rudimentary in appearance with larval prolegs still present (Figure 2A). On the other hand, treatment of $A$. indica leaves extract caused abnormal green unsclerotized pupal integument with larval exuviae attached to dorsal region of anterior part of the body (Figure 2B). Similar results were reported by Das \& Islam (2014) whose works showed that in fruitborer (L. orbonalis Guen.) (Lepidoptera: Pyralidae) treated with buprofezin caused developmental disruption.

Xavier et al. (2016) observed larval-pupal intermediate with improperly hardened pupal case and retained larval appendages in $S$. litura treated with the ferns Cyclosorous interruptus, Christella dentata and Nephrolepis cordifolia. Similarly, Ashwini et al. (2017) reported the pupal emergence inhibition activity of A. indica leaf extract against dengue vector,
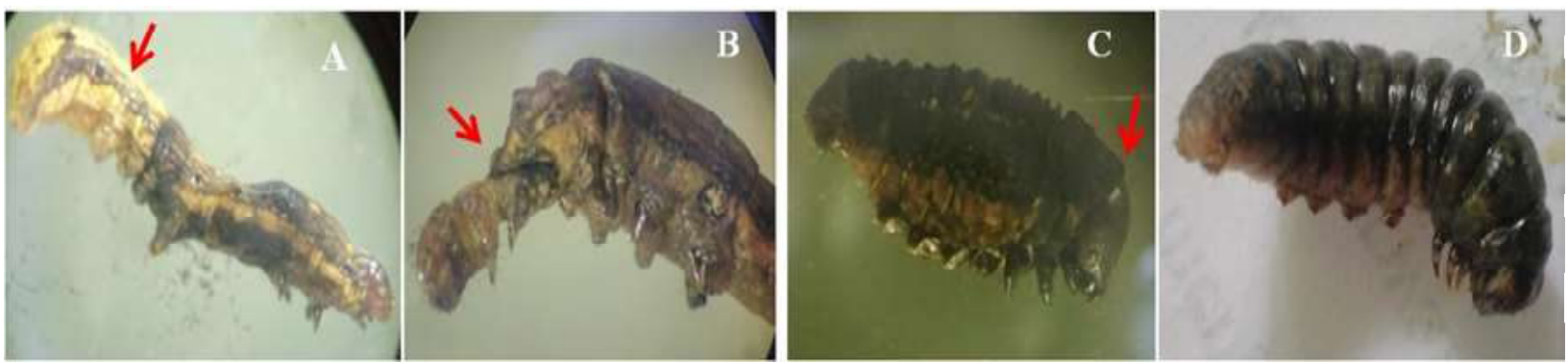

Figure 1. Various forms of larval abnormalities of S.litura growth due to larval feeding of leaf treated. (A) Triflumuron; (B) Buprofezin; (C) A. indica extracts; (D) Normal untreated larvae.
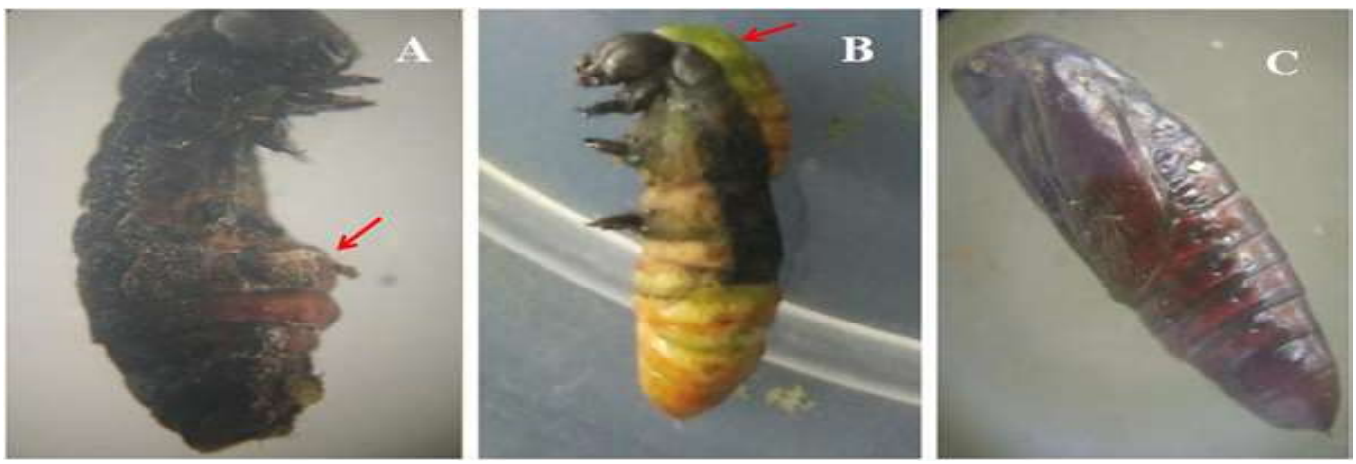

Figure 2. Abnormal of pupae of S.litura developed from exposed larvae fed on treated leaf. (A) Buprofezin; (B) A. indica leaf extracts; (C) Normal pupae developed from untreated larvae. 

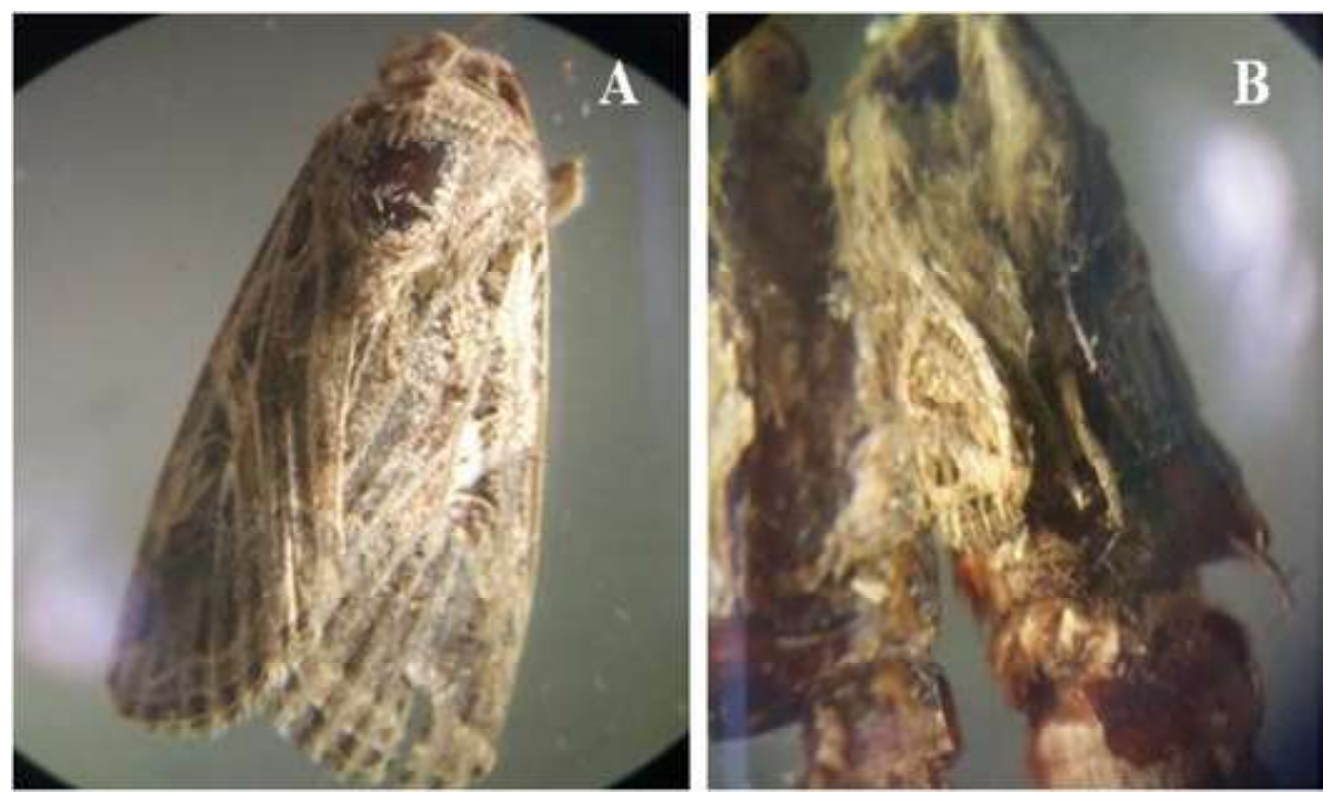

Figure 3. Adult S. litura emerged from pupae. (A) Normal adult which the larvae were fed with untreated (control) leaf; (B) Crumbled, deformed one emerged from pupae developed from larvae that were fed with leaf treated with extract of Acalypha indica leaf.

Aedes albopictus mosquito. Moreover, their study showed that the detrimental effect of $A$. indica was possibly because of alkaloids, flavanoids, tannin, steroids, terpenoids and phenolic compounds. Similar findings also reported by Sahayaraj \& Shoba (2012) who found $A$. indica extracts offer a wide array of bioactive compounds that disrupts normal insect development.

Our results indicated that $S$. litura survived to adult stage on those treated with $A$. indica leaves extract (Table 2; Figure 3). However, they showed pupal-adult intermediates with crumbled and deformed wings (Figure 3B), while all $S$. litura pupae of control molted into normal adults (Figure $3 \mathrm{~A}$ ). The results have demonstrated that the action of these botanical insecticides cause physiological disturbances leading to growth abnormalities like deformed adults. According to Ahmed et al. (1981), insecticidal potentials and biological activity $A$. indica extract caused deformation of emerged adults in Musca domestica. Such kind of detrimental effect has also been observed by Gaur \& Kumar (2019) in S. litura treated with medicinal plant, Ashwagandha (Withania somnifera).

\section{CONCLUSION}

Our results indicate that the mortality of S. litura showed significant difference between control and $A$. indica leaf extract and synthetic insect growth regulators triflumuron $\&$ buprofezin) at $1,4,8 \mathrm{~d}$ after treatments. The highest mortality $(100 \%)$ was found on larval $S$. litura treated with triflumuron at $4^{\text {th }}$ days after treatment and those mortality was significantly higher compared those with buprofezin and $A$. indica leaf extract. However, at the end of experimental period, all treatments caused high mortality of $S$. litura and those was significantly different compared with control. The aplication of all compound treatments caused not only mortality in larval stage, but also caused defects in pupal and adult stages, and in some cases produced larvalpupal and pupal-adult intermediates.

\section{ACKNOWLEDGMENTS}

We thank the Public Service Agency (Badan Layanan Umum $=$ BLU) the University Lampung for supporting this research.

\section{REFERENCES}

Abdel-Monem AH, Cameron EA, \& Mumma RO. 1980. Toxicological studies on the molt inhibiting insecticide (EL-494) against the gypsy moth and effect on chitin biosynthesis. J. Econ. Entomol. 73(1): 22-25.

Ahmad M, Arif MI, \& Ahmad M. 2007. Occurrence of insecticide resistance in field populations of Spodoptera litura (Lepidoptera: Noctuidae) in Pakistan. Crop Prot. 26(6): 809-817. 
Ahmad M, Ghaffar, \& Rafiq M. 2013. Host plants of leaf worm, Spodoptera litura (Fabricius) (Lepidoptera: Noctuidae) in Pakistan. Asian J. Agri. Biol. 1(1): 23-28.

Ahmed SM, Chander H, \& Pereira J. 1981. Insecticidal potentials and biological activity of Indian indigenous plants against Musca domestica L. Int. Pest Control. 23(6): 170-175.

Aitkenhead P, Baker CRB, \& Chickera GWD. 1974. An outbreak of Spodoptera litura, a new pest under glass in Britain. Plant Pathol. 23(3): 117118.

Ashwini U, Taju G, Thirunavukkarasu P, \& Asha. 2017. Pupal emergence inhibition activity of Acalypha indica leaf extract against dengue vector, Aedes albopictus mosquito. Int. J. Pharm. Sci. 9(8): 114-118.

Badawy MEI, Kenawy A, \& El-Aswad AF. 2013. Toxicity assessment of buprofezin, lufenuron, and triflumuron to the Earthworm Aporrectodea caliginosa. Int. J. Zool. 20(13): 1-9.

Bae SD \& Park KB. 1999. Effects of temperature and food source on pupal development, adult longevity and oviposition of the tobacco cutworm, Spodoptera litura Fabricius. Korean J. Appl. Entomol. 38(1): 23-28.

Brown ES \& Dewhurst CF. 1975. The genus Spodoptera in Africa and the near East. Bull. Entomol. Res. 65(2): 221-262.

Chen CN \& Hsiao HF. 1984. Influence of food and temperature on life history traits and population parameters of Spodoptera litura Fabricius. Plant Prot. Bull. 26: 219-229.

Das G. 2013. Inhibitory effect of buprofezin on the progeny of rice weevil, Sitophilus oryzae L. (Coleoptera: Curculionidae). J. Biofertil Biopestic. 4(2): 1-5.

Das G \& Islam T. 2014 Mortality and growth inhibition of brinjal shoot and fruit borer, Leucinodes orbonalis (Guen.) by buprofezin, a potent chitin synthesis inhibitor. J. Entomol. Zool. Stud. 2(6): 282-287.

Dhadialla TS, Carlson GR, \& Le DP. 1998. New insecticides with ecdysteroidal and juvenile hormone activity. Annu. Rev. Entomol. 43: 545569 .
Ecobichon DJ. 1996. Toxic effects of pesticides. In: Klaassen CD \& Doull J (Eds.). Toxicology: The Basic Science of Poisons. $5^{\text {th }}$ edition. pp. 643689. MacMillan, New York.

Fattah A. 2016. Siklus hidup S. litura (Spodoptera litura, F) dan tingkat serangan pada beberapa varietas unggul kedelai di Sulawesi Selatan. Prosiding Seminar Nasional Inovasi Teknologi Pertanian. pp. 834-842. Banjarbaru.

Farrar JJ, Ellsworth PC, Sisco R, Baur ME, Crump A, Fournier AJ, Murray MK, Jepson PC, Tarutani CM, \& Dorschner KW. 2018. Assessing compatibility of a pesticide in an IPM Program. J. Integr. Pest Manag. 9(1): 1-6.

Garad GP, Shivpuje PR, \& Bilapate GG. 1985. Larval and post-larval development of Spodoptera litura (Fabricius) on some hostplants. Proc. Indian Acad. Sci. 94(1): 49-56.

Gaur SK \& Kumar K. 2019. A comparative bioefficacy of seed and root extracts of a medicinal plant, Withania somnifera when administered to prepupae of lepidopteran insects, Spodoptera litura (Lepidoptera: Noctuidae) and Pericallia ricini (Lepidoptera: Arctiidae). J. Basic Appl. Zool. 80(37): 1-15.

Ghumare SS \& Mukherjee SN. 2003. Performance of Spodoptera litura (Fabricius) on different host plants: influence of nitrogen and total phenolics of plants and midgut esterase activity of the insect. Indian J. Exp. Biol. 41(8): 895-899.

Govindarajan M, Jebanesan A, \& Pushpanathan T. 2008. Studies on effect of Acalypha indica L. (Euphorbiaceae) leaf extracts on the malarial vector, Anopheles stephensi Liston (Diptera: Culicidae). Parasitol Res. 103(3): 691-695.

Ishaaya I, Mendelson Z, \& Melamed-Madjar V. 1998. Effect of buprofezin on embryo genesis and progeny formation of sweet potato whitefly (Homoptera: Aleyrodidae). J. Econ. Entomol. 81(3): 781-784.

Izawa Y, Uchida M, Sugimoto T, \& Asai T. 1985. Inhibition of chitin biosynthesis by buprofezin analogs in relation to their activity controlling Nilaparvata lugens Stal. Pestic. Biochem. Phys. 24(3): 343-347. 
Jepson PC, Guzy M, Blaustein K, Sow M, Sarr M, Mineau P, \& Kegley S. 2014. Measuring pesticide ecological and health risks in West African agriculture to establish an enabling environment for sustainable intensification. Philos. Trans. $R$. Soc. Lond. B. Biol. Sci. 369(1639): 1-18.

Kalshoven LGE. 1981. The Pets of Crops in Indonesia. PT. Ichtiar Baru Van Hoeve, Jakarta.

Kamalakannan S, Murugan K, \& Chandramohan B. 2015. Insect growth regulatory activity of Acalypha alnifolia (Euphorbiaceae) and Vitex negundo (Verbenaceae) leaf extracts against Aedes aegypti (Diptera: Culicidae). Int. J. Mosq. Res. 2(1): 47-52.

Kanaoka A,Yamaguchi R, \& Konno T. 1996. Effect of buprofezin on oviposition of brown planthopper, Nilaparvata lugens, at sub-lethal dose. $J$. Pesticide Sci. 21(2): 153-157.

Karimzadeh R, Hejazi MJ, Rahimzadeh KF, \& Moghaddam M. 2007. Laboratory evaluation of five chitin synthesis inhibitors against the Colorado potato beetle, Leptinotarsa decemlineata. J. Insect Sci. 7: 1-6.

Khan MAM. 2016. Efficacy of insect growth regulator buprofezin against papaya mealybug. JEZS. 4(4): 730-733.

Khatter NA. 2015. Chitinase gene mutations induced by two insect growth regulators in Spodoptera littoralis (Lepidoptera: Noctuidae). Life Sci. J. 12(1): 229-238.

Khatun MR, Das G, \& Ahmed KS. 2017. Potentiality of buprofezin, an insect growth regulator on the mortality of Spodoptera litura (Fabricius). JEZS. 5(2): 736-740.

Liburd OE, Funderburk JE, \& Olson SM. 2000. Effect of biological and chemical insecticides on Spodoptera species (Lepidoptera: Noctuidae) and marketable yields of tomatoes. J. App. Entomol. 124(1):19-25.

Manibala J \& Praveena A. 2017. A comparative study on the effect of pheromone baited traps and Acalypha indica extract on Leucinodes orbonalis. Intl. J. Bioinforma. Biol. Sci. 5(2): 127-134.
Marwoto \& Suharsono. 2008. Strategi dan komponen teknologi pengendalian ulat grayak (Spodoptera litura Fabricius) pada tanaman kedelai. $J$. Litbang Pertanian. 27(4): 131-136.

Merzendorfer H \& Zimoch L. 2003. Chitin metabolism in insects: structure, function and regulation of chitin synthases and chitinases. J. Expt. Biol. 206(Pt 24): 4393-4412.

Mohan SC, Dinakar S, Anand T, Elayaraja R, \& Priya BS. 2012. Phytochemical, GC-MS analysis and Antibacterial activity of a Medicinal Plant Acalypha indica. Int. J. Pharm.Tech. Res. 4(3): 1050-1054.

Nasr HM, Badawy EI, \& Rabea EI. 2010. Toxicity and biochemical study of two insect growth regulators, buprofezin and pyriproxifen, on cotton leafworm Spodoptera littoralis. Pestic. Biochem. Physiol. 98(2): 198-205.

Nazri NNM, Hazali N, Ibrahim M, Masri M, \& Ayo MK. 2016. Preliminary studies on Acalypha indica: proximate analysis and phytochemical screening. Int. J. Pharm.Sci. 8(3): 406-408.

Onstad DW, Crespo ALB, Pan Z, Crain PR, Thompson SD, Pilcher CD, \& Sethi A. 2018. Blended refuge and insect resistance management for insecticidal corn. Environ. Entomol. 47(1): 210-219.

Perry AS, Yamamoto I, Ishaaya I, \& Perry RY. 1998. Insecticides In Agriculture and Environment: Retrospects and Prospects. Springer, Berlin, Germany.

Pratiwi D, Prahastiwi EA, \& Safitri M. 2015. Uji aktivitas larvasida ekstrak etil asetat herba antinganting (Acalypha indica L.) terhadap larva nyamuk Aedes aegypti. J. Farmagazine. 2(1): $1-8$.

Rao GVR, Wightman JA, \& Ranga RDV. 1993. World review of the natural enemies and diseases of Spodoptera litura (F.) (Lepidoptera: Noctuidae). Insect Sci. Appl. 14(3): 273-284.

Retnakaran A, Granett J, \& Ennis T. 1985. Insect growth regulators. In: Kerkut GA \& Gilbert LI (Eds.). Comprehensive Insect Physiology, Biochemistry, and Pharmacology. pp. 529-601. Academic Press, New York. 
Sahayaraj K \& Shoba J. 2012. Toxic effect of Tephrosia purpurea (Linn.) and Acalypha indica (Linn.) aqueous extracts impact on the mortality, macromolecules, intestinal electrolytes and detoxication enzymes of Dysdercus cingulatus (Fab.). Asian J. Biochem. 7(3): 112-122.

Shahout H, Xu J, Yao X, \& Jia Q. 2011. Influence and mechanism of different host plants on the growth, development and, fecundity of reproductive system of common cutworm Spodoptera litura (Fabricius) (Lepidoptera: Noctuidae). Asian J. Agric. Sci. 3(4): 291-293.

Sharma A \& Gupta RK. (2009). Biological activity of some plant extracts against Pieris brassicae (Linn.). J. Biopesticid. 2(1): 26-31.
Uchida M, Asai T, \& Sugimoto T. 1985. Inhibition of cuticle deposition and chitin biosynthesis by a new insect growth regulator buprofezin in Nilaparvata lugens. Stal. Agric. Biol. Chem. 49(4): 12331234.

Xavier GSA, Selvaraj P, \& John N. 2016. Impact of phytoecdysone fractions of the ferns Cyclosorous interruptus, Christella dentata and Nephrolepis cordifolia on the biology of Spodoptera litura (Fab.). J. Biopest 9(2): 125-134.

Yang H, Qin CS, Chen YM, Zhang GY, Dong LH, \& Wan SQ. 2019. Persistence of Metarhizium (Hypocreales: Clavicipitaceae) and Beauveria bassiana (Hypocreales: Clavicipitaceae) in tobacco soils and potential as biocontrol agents of Spodoptera litura (Lepidoptera: Noctuidae). Environ. Entomol. 48(1): 147-155. 